\title{
CHAMANISMO Y ETNOTURISMO: La venta de rituales de ayahuasca' y la compra de sentidos en el alto Napo.
}

\author{
Pablo Andrés Hermida Salas. ${ }^{2}$
}

\begin{abstract}
No soy un borracho, pero tampoco un santo. Un hechicero no debería ser un "santo"... Debería poder descender tan bajo como un piojo y elevarse tan alto como águila... Debes ser dios y diablo a la vez. Ser un buen hechicero significa estar en medio de la tormenta y no guarecerse. Quiere decir experimentar la vida en todas sus fases. Quiere decir hacer el loco de vez en cuando. Eso también es sagrado.
\end{abstract}

Corzo Cojo (Brujo Siux de la tribu Lakota) ${ }^{3}$

\section{Resumen.}

La etnia Napo runa, se ha caracterizado por su configuración histórica de carácter aglutinante y por contener un rico bagaje de saber etno-médico. Evidentemente, es una etnia que ha tenido sucesivos contactos a lo largo del tiempo, razón por la cual se los ha revestido de innumerables imaginarios según los intereses establecidos y el tipo de encuentros.

Uno de los encuentros a los que aludimos, tiene que ver con la venta de rituales de ayahuasca por parte del chamán y su familia hacia los etno-turistas. En este encuentro se generan al menos dos tipos tensiones: las que se muestran a nivel interno, que tienen que ver con las relaciones de poder dentro de la familia del chamán y la comunidad; y a nivel externo, en las distancias culturales que ponen en cuestión y "préstamo" códigos simbólicos, de los que se valen tanto los Napo runas como los etno-turistas.

El presente estudio, pretende considerar al chamanismo como eje por el cual se mantienen y dinamizan los Napo runa según el contexto sociocultural. Desde esta premisa, veremos las formas en las que opera el chamanismo en este grupo étnico, enfocándolo a manera de un sistema cultural en el que subyace la economía del don. Esto dará cuenta del tipo de cambios que se presentan con la venta de rituales y por ello las coordenadas de reproducción cultural adoptadas como estrategias frente a la injerencia foránea en la contemporaneidad.

1 Nombre científico Banisteriopsis Caapi. Planta o bejuco presente en toda la hoya amazónica. Su preparación por cocción larga proporcionan estados alterados de la mente gracias a sus alcaloides que tienen propiedades narcóticas.

2 Licenciado en Antropología, PUCE,Investigador en la Unidad de Conocimientos Tradicionales del Instituto Ecuatoriano de la Propiedad Intelectual (IEPI).

3 Jodorowsky 2006, 17. 


\section{Abstract}

The Napo Runa ethnic group has been characterized by its historic configuration of binding character and for having a rich cultural baggage of ethno-medical knowledge. Evidently it is an ethnic group that has had successive contact throughout time, the reason for which it has been revisited in innumerable imaginations following the established interests and the type of encounters.

We allude to the type of encounter which exploits the sale of ayahuasca rituals on the part of the Shaman and their family to ethno tourists. It is an encounter which inevitably generates tension, which is shown on an internal level in the relations of power within the family or the Shaman and the community, and on an external level as the cultural distance that puts in question the "loaning" of symbolic codes, which are as valuable to the Napo runa as they are to the ethno tourists.

The nodal point from which we embark on the present study is the consideration of Shamanism as the axis on which the Napo Runa maintain themselves and diversify within a sociocultural context. On this premise, we will see the forms in which Shamanism operates in this ethnic group focusing on the way in which the cultural system is underlined by the gift economy.

This will reveal the type of change that is created by the sale of rituals and the cultural reproduction adopted as strategies faced with the foreign injections in contemporaneity.

$\mathrm{E}$ n la región del Alto Napo se asienta un grupo cultural indígena que está ubicado en las estribaciones amazónicas de la cordillera oriental o ceja de montaña, región muy próxima a la Sierra ecuatoriana. Caracterizados históricamente por ser una etnia que se configura por aglutinación de otras y con gran conocimiento en prácticas etnomédicas, los "Napo Runa"4, "Canelos kichwas" o también llamados "Quijos" han mantenido contacto permanente con actores foráneos a lo largo del tiempo, lo que naturalmente les ha conducido a incorporar referentes culturales externos, sobre todo en técnicas de salud y en sistemas económicos.

A partir de los años 70 el desarrollo de la industria petrolera tendió redes viales para dar cobertura a este vasto territorio de selva, lo que condujo posteriormente a facilitar la industria del turismo en la región, siendo el hábitat biológicamente megadiverso un elemento altamente atrayente para los turistas. Asimismo, lo fueron sus pobladores revestidos de imaginarios románticos como: "buen salvaje", "ecologistas naturales", etc., pero sobre todo lo que buscaban los turistas era el contacto con la persona que concentraba este "exotismo" cultural, y este sin duda era el chamán.

El apogeo del turismo en el Alto Napo sobrevino a finales de los años 80, siendo en la actualidad un importante ingreso económico en la región. Es una empresa relativamente nueva que oferta actividades variadas, las que se incrementan cada vez más.

Una de las actividades ofrecidas sin avisos ni promociones explícitas es la venta de rituales tradicionales de Ayahuasca con o sin su ingestión, actividad en la que participará

4 Los Napo Runa pertenecen a un solo grupo conocido como "Quichuas del Oriente", en el que se incluyen los quichuas del Alto y Medio Napo como de la provincia de Pastaza. 
por lo general el chamán con el fin de curar al paciente turista en caso de enfermedad o para limpiar el espíritu del turista en caso de solicitarlo. Sin embargo, los rituales tradicionales de Ayahuasca siempre se han constituido como un tema "tabú", siendo criminalizado en un tiempo, otrora invisibilizado, y por último dejados de lado sin el merecido tratamiento frente a la demanda turística actual.

De esta forma, las culturas de selva tropical se convirtieron en un atractivo turístico importante, siendo la figura del chamán recubierta por el imaginario turístico de varias cualidades, por ejemplo, como un ser de importancia casi sacerdotal, dueño y portador de poderes mágicos, capaz de cambiar la realidad de las personas o de transportarse a otras. No obstante, la afluencia turística aupada por estas cualidades adscritas no vino sola, vino de la mano del auge de una nueva corriente religiosa llamada "New Age", que incorpora dentro de sí referentes religiosos de otras culturas, en este caso referentes a las técnicas de sanación y cosmovisión de la medicina natural y sobre todo del éxtasis chamánico.

Para el presente trabajo se estudió la venta de rituales de un chamán que trabaja con su familia extendida. En los rituales que venden se tejen cortas e intensas relaciones sociales, se puede decir que se gestan continuamente relaciones de tensión no declarada, sea por el idioma, por los códigos culturales, las costumbres o por la compra misma que incluye el uso del valor dinero para la experiencia del ritual y del sentido de éste. Inevitablemente se ponen en juego relaciones sociales de poder, al interior de la familia y al exterior con la comunidad; relaciones que se muestran en la dinámica de intercambio social ceñido a la economía del don -dar, recibir y devolver-, que estará conferido por "lo que se guarda" en el ámbito de lo sagrado dentro el chamanismo.

Este trabajo constituye un segmento de una investigación de tesis que abordó en extenso el trasfondo histórico cultural y el estudio anacrónico del chamanismo Napo runa, lo que brinda una mejor comprensión de su sucesión cultural en el tiempo. Sin embargo, por razón de espacio hemos circunscrito el tópico a un tiempo sincrónico teniendo que dejar de lado éste y otros temas de estudio.

El objetivo del presente artículo será mostrar brevemente la dinámica cultural que opera con la venta directa de rituales de ayahuasca a los etnoturistas, no sin antes ilustrar el modus operandi de su sistema cultural chamánico. Con esto podremos identificar el tipo de cambio cultural que se estaría gestando, ora hacia una adaptación en transición como resistencia cultural, ora hacia el desarraigo como aculturación, es decir, las coordenadas "Napo runa" en tiempos de globalización y desenfadada modernidad.

\section{Breves consideraciones para el estudio del chamanismo en los Napo Runas}

Acercarnos al tema del chamanismo en la cultura Napo y la relación con el Etnoturismo evidentemente tiene varias aristas. Hacer el análisis de éstas desde una sola teoría restaría la capacidad explicativa de las vertientes culturales de los dos mundos en cuestión. De tal forma, se optó por abordar el tema partiendo de la Etnomedicina, ya que permite un enfoque multidisciplinario para el análisis de temas como lo religioso o lo sagrado vinculándonos esencialmente al ámbito de la salud en su más amplio sentido.

Bajo este enfoque, partimos de la premisa de que las prácticas chamánicas de ayahuasca en los Napo Runas puede entendérselas como técnicas para obtener salud y también como prácticas por las cuales se reconfigura su cultura. 


\begin{abstract}
"Su saber médico tradicional (Napo runa) será un sistema coherente de nociones, conceptos, reglas, tendientes a conservar la salud. Hay interacción del medio ambiente y sociedad. Se enfatiza en el manejo de "fuerzas equilibrantes", provenientes de la misma naturaleza. La medicina tiene un sistema totalizador que reafirma su identidad cultural” (Iglesias s/f).
\end{abstract}

Por lo tanto, hemos dejado entrever (afirmamos) que el eje transversal por el cual la cultura "Napo Runa" se ha desenvuelto es el chamanismo, práctica que se conoce ancestralmente desde los albores de las culturas de foresta tropical, siendo en la actualidad un ámbito nodal en el que se resignifica al medio circundante dando sentido a la realidad.

Siguiendo con lo anterior, los rituales de ayahuasca serán naturalmente los espacios culturales en los que se condensa el chamanismo, espacios de reconfiguración de sentidos y naturalmente de poiesis cultural.

Para explicarlo mejor, debemos tratar a los rituales de ayahuasca como prácticas adscritas a una forma de religiosidad, debido a que en ella estarán los aspectos normativos, morales y estéticos por los que se ha de desenvolver la cultura.

En otras palabras, la religión sería el mecanismo culturalmente más poderoso, puesto que en él se condiciona la manera de actuar y ver la realidad mediante los prejuicios o las formas de vida preescritas que encierra, así es como Cliford Geertz manifiesta que los seres humanos tratarán de mantener su cultura a través de dos aspectos clave: "el ethos", que son los aspectos evaluativos de la persona como el estilo y modo moral y estético, y "la visión del mundo", que son los aspectos existenciales y cognitivos, por ejemplo de como son las cosas en la realidad o el concepto de naturaleza y de sociedad. Estos serían dos aspectos que van de la mano y la religión será la instancia más poderosa para mantenerlos en concordancia. La creencia y el ritual se confrontan y se confirman mutuamente, el ethos se hace intelectualmente razonable por cuanto abandera un modo de vida que corresponde a lo descrito por la visión del mundo (Geertz, 1973: 16).

Así, los Napo Runa se ceñirán a su cultura creyendo y redefiniendo, por un lado, al compendio de sus mitos cosmogónicos y creencias de lo supraordinario "no material", y por otro lado, a la observancia de normas como las de jerarquía y poder social; o las de cacería; creencias y prohibiciones en la cotidianidad; prescripciones para recobrar la salud; la interpretación de sueños que son coordenadas para acción diaria, etc. Lo que da como resultado la configuración dinámica en "un todo" ordenado, es decir, la cultura entendida como un sistema de interacción de signos interpretables que dan y a la vez se nutren de sentido constantemente, constriñendo la conducta de quienes la portan.

Los espacios rituales de ayahuasca dan cabida sociocultural para que en él se condensen gran cantidad de símbolos provenientes de mitos cosmogónicos, de cuentos, y de creencias propias de su cultura, de manera que se tratará de un espacio religioso en donde se configura un tiempo dentro de un espacio distinto, y éste es el tiempo de lo sagrado o que se re-liga con lo divino supremo, como lo veremos más adelante.

En este espacio los símbolos son esencialmente los vehículos que portan significados, y que, puestos en acción, configuran el ritual. Entonces serán los encargados de traer al presente el tiempo de los mitos contados por sus antepasado, de generación en generación, ya que el símbolo no solamente cuenta intelectivamente el pasado sino que lo reactualiza en el presente poniéndolo en consonancia con la emoción que trasluce, su hondura es justamente el poder de evocación de lo indecible, de develar lo innombrable, y que tan 
sólo es patente en la emotividad que suscita en quien lo pronuncia y para quien lo escucha (Rueda, 1993).

En este punto ya nos hemos acercado al campo que se suscriben los rituales de ayahuasca, pero cabe adentrarnos a conocer a los agentes culturales que manipulan la planta y la manera de inducir a estados de conciencia alterados.

Para empezar, debemos señalar que el manejo de estos rituales está supeditado a una sola persona o a un sólo especialista cultural. Comúnmente, para la gente en general o para los turistas esta persona es conocida como "chamán", pero dentro de los Napo Runas es llamado Yachac, que bien puede ser hombre o mujer, aunque el último caso no es muy común.

Hay que llamarlo Yachac por la especificidad que encierra su nombre dentro del tipo cultural en el que se inserta. Yachac quiere decir "el que conoce", "el sabio" o "el sabedor"; para convertirse en uno, el agente cultural deberá haber tenido algún suceso que le marque la vida o tal vez una señal que le incline por este rol. Su preparación empieza desde muy temprana edad, o lo que se llama "iniciación" y consiste en largas sesiones de aprendizaje con un viejo Yachac, quien le guiará en el largo camino del conocimiento, le enseñará sobre plantas medicinales, relatos de mitos y seres que se encuentran en la naturaleza, preparación de pócimas y, sobre todo, técnicas para preparar a la mente y al cuerpo como ayunos y prohibiciones de comportamiento, para finalmente poder asumir la capacidad de manejar fuerzas invisibles y ser reconocido a lo largo del tiempo como Yachac en su comunidad y luego en sus alrededores. En este caso el espacio privilegiado para obtener el poder necesario es el sector de selva de "Napo Galeras", que se encuentra en la actualidad dentro del parque Nacional Gran Sumaco.

El Yachac será entonces el agente principal que maneja el bagaje simbólico-ritual de su cultura, de esta manera, sus funciones serán: la cura de enfermedades, predicciones del futuro, interpretación de augurios, protección de la comunidad de elementos de destrucción, garantía de la caza, distribución de fuerza mágica y organización y dirección de ceremonias y danzas religiosas (Sharon, 1998:193).

En definitiva es un ente que concentra varias funciones, las que podríamos agruparlas dentro de lo que es un guía espiritual o guía religioso, encargado de la protección, sanación y conocimiento dentro de la comunidad.

La función primordial del Yachac como agente cultural de sanación y guía espiritual es la de recobrar la salud individual y colectiva en la comunidad, es decir, devolver el balance en su cultura. De tal forma que se apoya en las plantas medicinales circundantes que le brindan sus propiedades benéficas, tanto químicas como simbólicas puesto que las plantas tendrían su propio espíritu que participan en la sanación.

Para cumplir su rol el Yachac emplea principalmente ritos ceremoniales, en éstos se encarga de autoinducir a estados alterados de conciencia que se logra con la ingesta de

5 “Chamán” es una palabra Tunguso-Siberiano que significa "Hombre-Dios-Medicina" (Hampejs, 1995). Fue acuñada y popularizada en todo el mundo por las investigaciones realizadas en esa zona. Es de mencionar que la palabra ha sido mal empleada ya que generalizó la idea de un estereotipo alrededor de las culturas del mundo en cuanto a la persona encargada de celebrar rituales con pócimas alucinógenas. Es decir que en principio se trata de un colonialismo semántico. 
la pócima hecha a base de la planta de ayahuasca, provocando trances extáticos -“vuelos mágicos"--

Usualmente, para referirse a los efectos inducidos de la ayahuasca se los ha tratado de llamar como efectos "narcóticos" "psiquedélicos" o "alucinógenos"; no obstante, al ingerirse dentro de un contexto ritual religioso la pócima y sus efectos tendrán otras connotaciones, el Yachac entrará en contacto con otras realidades o con un "mundo" no perteneciente al de su cotidianidad, pudiendo dialogar con seres inmateriales, tendiendo una comunicación efectiva con entidades y objetos que materializan símbolos fuera del cotidiano de la comunidad.

De forma que se entabla una comunicación a través de símbolos profundos que reconfigura el espacio dentro de un tiempo de lo sagrado, es lo que Valentin Hampejs conoce como la capacidad de este especialista en tener una comunicación efectiva entre "éste" y algún "otro mundo" (Hampejs, 1995: 165-170).

Así, en esta mediación, el Yachac obtiene "visiones" o clarividencias del pasado, del futuro o interpretaciones del presente, obteniendo el poder curativo, visionario, predictivo e interpretativo de la realidad, el cual lo aplica en los tratamientos curativos como las fricciones (sobas), succiones (chupados), aventamientos y vaporizaciones; y adopta el rol de intermediario entre el mundo natural y social; entre el mundo social y el sobrenatural, lo que indudablemente englobaría a las prácticas etnomédicas y religiosas en los Napo Runas (Iglesias.s/d., 82).

“...el depositario de los conocimientos tribales, incluidos los mitos y creencias, es el yachac; ya que él es quien dirige la ingesta, al igual que direcciona el trance psíquico del individuo o la llamada “despersonalización” / “impersonalización” (Naranjo , 1983: 40).

Con lo anterior podemos decir que la ayahuasca no sería un simple narcótico o una "droga", sino que constituye un elemento de vital importancia para el desenvolvimiento cultural, es menester nombrarla acorde a las propiedades que guarda en su contexto cultural. Por eso la catalogaremos de mejor manera como un "enteógeno" (Fericgla, 1999: 35, 87), término que guarda las resonancias culturales acertadamente, y se refiere a "sustancias que, cuando se ingieren, proporcionan una experiencia divina” (Wasson, 1983: 30).

Cabe resaltar que con los efectos de la pócima de la ayahuasca, objetivamente hablando, no se perdería en ningún momento la memoria de la persona (Escohotado, 2002:164), de manera que no se trata de una alucinación puesto que la persona sabe y reconoce el estado en el que está viviendo, lo podrá recordar cuando el efecto se haya desvanecido por completo. Mejor dicho se trata de un "trance psíquico" o más conocido como "viaje mental", en el que se agudizan las experiencias sensoriales y emocionales en el individuo, las que permiten un estado de conciencia distinto y también un aprovisionamiento de experiencia y conocimiento en el individuo y en su colectivo. Será pues un saber que se abre paso en el tiempo ritual sagrado con base en el bagaje cultural mítico.

El estado de "trance psíquico" o estado alterado de conciencia se lo conoce como el "éxtasis chamánico de la conciencia", cuestión que se explica como un "dialogismo mental" (Fericgla, 1998: 120, 130), inducido por la planta y gracias a la mediación del 
Yachac. En otras palabras, los sectores conciente e inconciente del cerebro se conectan mediante los símbolos guía del Yachac, estableciendo una comunicación efectiva en pro de la salud del agente cultural y el de la comunidad.

El Yachac se convierte en un intermediario entre los mundos "material" e "inmaterial", se comunica con las fuerzas espirituales presentes y poderosas en los seres vivos e inertes. El ser un guía espiritual quiere decir actuar como interlocutor para canalizar fuerzas que guíen, protejan y recobren la salud, de manera que estas funciones también lo ponen en la función de terapista a la vez. De lo último, se deriva que el Yachac prescribe conductas a partir de interpretaciones o de manifestaciones simbólicas, por esta razón constriñe el accionar de los individuos para que se apeguen al ideal de ese "todo" cultural.

En este punto cabe reiterar que las prácticas etnomédicas cumplidas dentro de un ritual estarán dentro de un código cultural al cual el Yachac (chamán) se debe y que a la vez lo reactualiza en dinamismo (Hampejs, 1995: 165). Por tratarse de un ámbito que refleja alta significación en una totalidad, hemos venido diciendo que estaría netamente dentro del campo de lo sagrado en una religiosidad, la que debe catalogársela como una "religión tradicional", a diferencia de la religión occidental que estaría más racionalizada y confinada su ritualidad a ciertos momentos y a ciertos espacios, la primera se manifestaría a todo momento en la cotidianidad de los individuos (Geertz, 1997: 152-154).

La cosmovisión Napo Runa está presente en su propia cotidianidad, pero el tiempo de lo sagrado establecido por los rituales de ayahuasca permite que se cumplan las funciones: curativa, religiosa y política. De manera que, el Yachac busca en el ritual la conjugación de las tres para recobrar la salud cultural del individuo en el colectivo y restablecer el equilibrio social, asegurando su reproducción cultural.

Es en este sentido que vemos a la toma de ayahuasca como un fenómeno de la Etnomedicina que reproduce a la sociedad en su totalidad, considerando que el grado de integración de la medicina como un todo y la medicina en su totalidad en el contexto de la cultura, varía considerablemente (Sanhueza, 1986).

\section{La cosmovisión Napo Runa}

A lo largo del tiempo el chamanismo y el papel del Yachac se han modificando sustancialmente. Por ejemplo, a principios de la colonia los Yachac tuvieron un papel preponderante en lo socio-cultural, puesto que en la región organizaron batallas de resistencia frente a los conquistadores españoles. No obstante, la conquista finalmente se dio pero con grandes variantes a como lo fue en el modelo de la sierra. En estos vastos lugares de selva fue muy difícil controlar la mano de obra (medios de producción) y la subyugación a un poder centralizado en las reducciones.

De manera que algunos autores, entre ellos Blanca Muratorio (1987) habla de una cultura en "resistencia", la cual todo el tiempo ha estado incorporando referentes externos dinamizando su cultura, a esto se lo ha llamado como sincretismo. Para el presente caso, pensamos que no conviene hablar de sincretismo sino más bien se trataría de un "camuflage" de sus formas culturales, para ilustrarlo mejor, podría decirse que en algunos casos han adoptado nuevos nombres para referirse a viejos conceptos o a sensibilidades propias de su cultura. En otras palabras, lo que se modifica son las formas pero lo que se 
mantiene es el fondo, y éste será una constitución cultural sistémica como lo veremos más adelante.

Ciertas características socioculturales, se han mantenido en consonancia con su sistema. Cabe presentar que ciertos elementos culturales son esencialmente importantes para comprender su dinámica a un nivel. Entre las características que consideramos básicas de la cultura Napo Runa tenemos: el animismo, el principio de complementariedad y el de reciprocidad.

El animismo es la forma de ver al mundo dotado de vida propia, todo ser tendrá un ánima independiente pero siempre en relación con el conjunto de los otros seres, sean vivientes o inertes, sea un jaguar o sea una roca, lo que interesa es que todos serán entidades con vida y no serán entendibles en su separación, pero esto sólo puede suceder porque tienen el elemento vital que es el denominado samay, elemento dador de vida o el espíritu que complementa el plano de lo aparente (que será el mundo físico, visible o mundo material). Es decir, que la cosmovisión Napo-Runa privilegia el mundo de lo invisible o sobrenatural (Goldaráz, 2004: 24), éste será pues el mundo verdadero que es influido por el mundo superfluo del cotidiano mundo visible "material".

En el mundo de lo invisible "inmaterial" podemos dividir a los seres sobrenaturales a grandes rasgos en: divinos, semidivinos y en espíritus o ayas (almas de plantas, objetos o personas que deambulan por la selva). Las dos categorías primeras se refieren a seres primigenios de la cultura y se encuentran enunciados en mitos como el famoso mito Napo Runa de los gemelos Kuillur y Ducero, mientras que el tipo de los espíritus ayas se encuentran más cercanos a la convivencia con la vida de los Napo Runa en general, sobre todo en las áreas de selva diversa como es la región de Napo Galeras.

La complementariedad se la observa en todo momento y puede ser entendida como una forma dual o binaria pero que se complementa "opositivamente", logrando cierto equilibrio dinámico (Khon, 1992). Por ejemplo, habrá sexuación en todos los elementos de la naturaleza, incluso el género del elemento varía de acuerdo al género de la persona que la observa. Otro ejemplo, volviendo al caso anterior, será la complementariedad existente entre el plano material visible y el plano etéreo invisible, pero que en la práctica el plano de lo invisible necesariamente es de mayor importancia puesto que aquí se encontrará el elemento que anima la vida que es el samay. De manera que los mitos, sueños, cuentos, creencias y visiones encontrarán gran resonancia justamente por remitirse al mundo de lo invisible, de ahí la importancia del éxtasis de la conciencia que propicia el Yachac con los rituales de ayahuasca; en estos espacios se vale de gran cantidad de símbolos que serán los vehículos necesarios para lograr la confluencia y complementariedad entre los mundos visibles e invisibles. Esta conjugación, en la que asisten sensibilidades de tipo afectivo emocional, crea integración complementaria de los elementos que las rodean, de tal forma que así se consigue un tipo de conocimiento que busca ubicar la armonía en todos los componentes.

Por último, el principio de reciprocidad (solidaridad), es una normativa contenida en la cultura Napo Runa (y en otras de la cuenca amazónica) que establece una regulación tácita por la que se ha de devolver lo que fue dado, y en el cual cualquier intento de mezquindad material, temporal o de mano de obra, es muy mal visto por la cultura y es condenado a fuerza de chismes y habladurías, y hasta reprimido por maleficios chamánicos o castigos físicos. 
Los elementos que hemos nombrado son formas culturales de mantener estable el dinamismo de los Napo Runas y son mecanismos presentes e implícitos en las relaciones socioculturales, pero hay que mencionar que a la par existen otros mecanismos que se manifiestan en la realidad. Es decir, que los primeros están en el plano de las relaciones sociales prefiguradas en el imaginario, mientras que las que mencionaremos a continuación serán cualidades manifiestas, presentes y establecidas en la propia configuración social y en el medio circundante. Estos elementos se han mantenido en dinámico balance y son los que han permitido la pervivencia del trasfondo cultural sistémico: la cohesión social manifestada en la organización de la familia extendida llamada ayllú ${ }^{6}$, el Yachac como agente que induce a estados alterados de conciencia y de memoria cultural y la presencia del medio biológico megadiverso.

En resumidas cuentas, estas tres variables se han mantenido en el tiempo reformulándose, pero en el fondo siguen cumpliendo una interrelación precisa que mantiene su cultura. De manera que, la cohesión Napo Runa se mantiene en la actualidad por ser familias extendidas, a lo que sin lugar a dudas el Yachac aporta como epicentro cultural con su función integradora, y para ello se vale de la planta de ayahuasca así como del medio circundante con la variedad biológica necesaria como fuente de alimentos, plantas medicinales, animales, lugares sagrados. Éstos no son sino referentes simbólico-culturales por los que sostiene y se sostiene su cultura.

\section{El don en su sistema cultural chamánico}

En lo que va del texto nos hemos referido vagamente a "un todo" cultural, bajo el enfoque de la Etnomedicina hemos resaltado la importancia de los rituales de ayahuasca y la del Yachac como epicentro cultural. Siguiendo esta lectura, la cultura Napo Runa comprende un sistema cultural que contiene cualidades establecidas en varias esferas. El investigador Joseph Fericgla establece que son tres:

1) Función religiosa.

Hemos mencionado el carácter religioso que tiene el rito con ayahuasca y el accionar del Yachac en estos espacios.

2) Función curativa

La función del Yachac en los ritos busca el inducir a estados alterados de conciencia por ser considerados como una vertiente terapéutica.

3) Función política.

La decodificación de la imaginería mental a partir de los rituales, o por ensoñaciones, por alteraciones del cuerpo, sueños, etc., constituye una interpretación y por ende una guía de cómo proceder como un recurso de adaptación y toma de decisiones, hay una visión del mundo y un "deber ser" que puede catalogarse como una postura política frente a la vida (Fericgla, 1998: 116).

6 Integración en la complementariedad y que se manifiesta como forma de pensamiento colectivo expresado en los mitos (Goldáraz, 2004: 33). 
La interrelación de estos tres aspectos confluye para formar un todo, que es como se compone un "sistema cultural chamánico". Se lo puede ver claramente si consideramos que atañe a varios ámbitos sociales y culturales a la vez, es decir que el accionar del chamanismo más que una "cura" constituye una forma de "sanación". Y esta sanación se logra al mantener la salud en equilibrio, por ejemplo, los lugares sagrados (que son esenciales y contienen plantas, animales, humanos y objetos inertes) para los agentes Napo Runas estarán plenamente simbolizados. Esto hace que se configure el espacio como una geografía sagrada cargada de una concepción animada de todo lo existente que es posible en la medida en que convergen tres rasgos comunes: identificatorios, relacionales e históricos, que se integran en lo que Marc Augé (2004) denomina "lugares antropológicos"

El Yachac de este estudio pone constantemente en juego la identidad y la relación que reactualizan el simbolismo religioso, lo cual se logra con esta intermediación con los espíritus, lo que sintoniza al colectivo cultural con el mundo de lo sagrado guardando relación con el reconocimiento físico de los lugares espirituales. La montaña próxima de Galeras es un gran referente que se manifiesta en los mitos no sólo de su cultura, también es mencionada por otras culturas amazónicas distantes, razón por la que se constituye en un punto de referencia cultural.

$\mathrm{Y}$ a esto nos referimos cuando se contempla varias aristas que son tocadas a la vez. De manera que podemos ver que el Yachac y su propia colectividad ayllu constituyen un sistema como un todo, pero con la diferencia de que el primero es el principal portador de creencias, intérprete de la realidad e intermediario con el mundo invisible. Es un guía que pregona valores o modos de vida en correspondencia con los actos ideales para su cultura. El chamanismo del Yachac tiene elementos de "magia" al interferir directamente para obtener cosas en la realidad, y de religión al pregonar y contener una serie de creencias acerca de la realidad. No obstante, interrogarse si la identidad del chamanismo es de carácter mágicoreligioso o si se trataría mas bien de una religión en sí, se diluye al considerarlo como un sistema cultural chamánico y no como una parte, ya que en un sistema los elementos, neutros de por sí, tendrán función sólo en la relación con los demás. Queda patente que el chamanismo cubre un radio de acción bastante amplia: “... el chamanismo (es) un hecho social que atañe tanto al conjunto de la sociedad y de sus instituciones, un hecho a la vez religioso, simbólico, económico, político, estético..." (Perrin, 2002: 7).

El Yachac es quien concentra las funciones y dinamiza el sistema cultural chamánico, mientras que la celebración de rituales serán los espacios de cohesión social en los que se reactualiza a la cultura. Pero en este estudio lo que consideramos que actúa como verdadera argamasa del sistema es el mecanismo que subyace en la cultura Napo Runa, y éste es el don.

"La economía tradicional de los indígenas amazónicos es esencialmente una economía del don, es decir, tiene como base el intercambio diferido de bienes... a cada miembro se le enseña el imperativo moral de recibir lo que le es ofrecido, con lo que reconoce la relación creada a través de la deuda" (Smith, en Wray, 1996: 300).

El don conceptualizado por el etnólogo francés Marcel Mauss como: dar-recibirdevolver, encierra la obligatoriedad social de dar perennemente; no obstante, es 
reformulado por Maurice Godelier (1998: 55), al notar un vacío explicativo en tanto presume que se cancelaría la continuidad del don al quedar saldado con el "devolver". Para ello Godelier afirma que para que el sistema funcione perennemente es necesario que existan cosas que no han de ser circuladas, serían las encargadas de que la cadena del don se mantenga (en permanente deuda o en diferencia). En otras palabras, el autor afirma que deben existir cosas que han de tener alto valor simbólico como para que no puedan ser ni donadas ni vendidas, la cadena requerirá de cosas que se puedan guardar para (poder) donar otras, con lo que se establece la cuarta obligación del don. Por eso se los considerará "objetos sagrados" y estarán en manos de personas que detentan un rol social alto, jerarquía y consecuentemente una alta influencia política. En este caso nos estamos refiriendo naturalmente a un Yachac, puesto que concentra funciones sociales en torno a un "sistema cultural chamánico", en el que cumple el tipo de jerarquía política, terapéutica y religiosa, bajo el cual, actúa y se relaciona en el ámbito familiar del ayllu y en el ámbito social Napo Runa mediante relaciones de intercambio.

El Yachac al ser el "especialista de lo sagrado", es quien controla a estos objetos o cosas "sagradas", las que permiten la circulación de los objetos "preciosos". Así a continuación tenemos a los objetos sagrados guardados o no donados que necesariamente aluden al mundo de lo sobrenatural y por los cuales el Yachac adquiere el control sobre los poderes que estarán presentes en los supays (demonios) o espíritus ayas presentes:

- La geografía sagrada de Napo Galeras que se constituye en un territorio ancestral a manera de cartografía espiritual por los seres que en él se encuentran.

- Los secretos de "iniciación chamánica" que son relatos, mitos, cuentos y encuentros con espíritus que el aprendiz de Yachac tiene en su preparación, conocimiento que no debe por ningún motivo contar a la colectividad sino únicamente a su sucesor.

- Poderes adquiridos de los espíritus "guardianes" o supays que poseen los animales y las plantas animadas de la selva. El poder será el saber gobernar a las ayas de los seres y los poderes que concentran mediante acciones chamánicas, es un saber que no ha de ser enteramente trasmitido o traspasado a su aprendiz sino hasta antes de su muerte.

- Piedras que concentran (físicamente) el poder para la acción mágica; son piedras que tienen el aya (espíritu) de algún difunto ancestro Yachac poderoso.

Por otro lado, tenemos a ciertos objetos llamados "preciosos", los cuales circulan gracias a la existencia de los primeros mencionados. A diferencia de los objetos “preciosos", las cosas "sagradas" (que se guardan) tendrán una conexión profunda con el ámbito invisible de las divinidades, los espíritus y el poder chamánico. Los Napo Runas tendrán un vínculo estrecho mediante la cuarta obligación del don, o mejor dicho, tendrán una relación de deuda que es el mecanismo que junta las dimensiones de lo sagrado con lo profano, se tiende así un puente entre los dioses y los humanos, para lo que el Yachac es el intermediario de esta relación básica y la pócima de ayahuasca será el canal que conciente el contacto religioso. 
Para ilustrar este punto tenemos al mito cosmogónico fundamental de los gemelos Kuillur y Ducero, quienes serían los primeros seres semi-dioses o semi-humanos que tuvieron las técnicas chamánicas para transformar las cosas e influir sobre la tierra. Cuentan los mitos que ellos usaron el engaño y sus poderes mágicos para evitar que los Napo Runas sean exterminados por los jaguares de aquellos tiempos, ellos los habrían matado y al último jaguar encerrado en una cueva de la montaña Galeras.

De manera que se los ve como héroes míticos, a los que innegablemente se les debe las condiciones de existencia cultural como sociedad Napo Runa. Lo que se traduce en la donación del "don primigenio", el cual no tiene ninguna motivación previa que lo justifique; por él la sociedad Napo Runa pudo sobrevivir y como tal es un don que generó deuda y la consecuente obligatoriedad de saldar lo que nunca podrá ser pagado debido a su propia magnitud.

La deuda innegablemente genera asimetría de poder, niveles y roles, esta característica es lo que mantiene la lógica del intercambio que recrea jerarquías tanto con los seres invisibles como con los agentes culturales vinculados a ellos.

Como habíamos dicho, la jerarquía del Yachac le permite ser intermediario con este mundo divino y establecer comunicación mediante el éxtasis de la conciencia. El puente comunicativo que se tiende, es un tipo de relación que exige el realizar "contradones" por parte del Yachac o de su ayllu hacia los seres divinos para poder obtener beneficios de ellos, caso contrario los poderes de las ayas (plantas y animales) se volverían en contra de él y de su comunidad.

Pero los dones no solamente se los hace de los hombres a los dioses, sino también se los hace de los hombres a los hombres que representan dioses, con ello no afirmamos que el Yachac asume la postura de una divinidad o semi-dios, pero sí un intermediario directo con las divinidades, quienes a través de él actuarán en y para el colectivo. Pero para que esto suceda se requiere devolver siempre los dones mediante el traspaso de objetos "preciosos", mejor dicho se requiere de "contradones" como plegarias, ofrendas, bienes e incluso sacrificios.

"Para retornar al don (...), recordemos que las creencias surgen de lo imaginario y que con ellas, nace la distinción entre lo sagrado y lo profano, en suma, el mundo de los religioso y de lo mágico, un mundo fundado en la doble creencia de que, por un lado existen seres y fuerzas invisibles que controlan el orden de la marcha del universo y de que, por otro, el hombre puede influir sobre ellos mediante la plegaria, el sacrificio y la conformidad de su conducta a lo que imagina son sus deseos, sus voluntades o su ley" (Godelier, 1998: 47).

Entre los ejemplos de "contradones" tenemos las ofrendas de carne dejadas en las cuevas por el Yachac a sabiendas de que jaguares acuden a esos lugares. Cabe mencionar que los jaguares son vistos como dioses tectónicos, seres que encarnan a sus antepasados Yachac poderosos y que ahora moran en otro estrato. Son referidos en los mitos cosmogónicos como seres superiores y de gran poder.

A continuación podemos reseñar la dinámica explicada en base a la ilustración. 


\section{El don en el Sistema cultural chamánico Napo Runa}

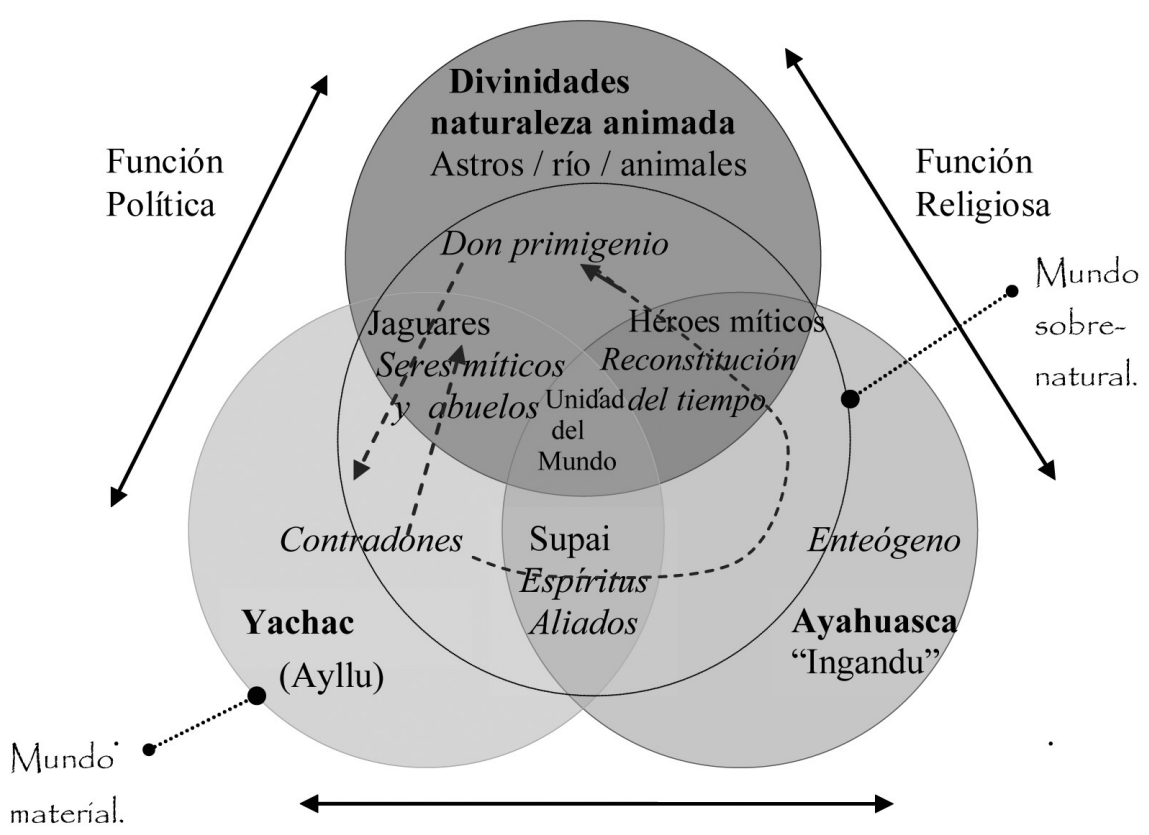

Función Curativa

Ilustración: Pablo Hermida S.

En la ilustración se indica que la acción de los rituales de ayahausca ocupa una esfera fundamental para la interrelación de las otras. Para el caso podemos decir que mediante el trance de la conciencia se da paso a técnicas cognitivas, que permiten reformular la cultura e interpretar el mundo en el que también intervienen objetos cargados de alta significación.

"...la mente humana habla consigo misma, se auto-observa, reelabora sus contenidos emocionales recientes y lejanos, toma conciencia de sí misma, (...) (y) la proyección psicológica: percibir como exógeno algo que es endógeno... La facultad para autoorganizarse permite a nuestra mente funcionar creando, por y para sí misma, aquello en lo que puede reflejarse y viceversa, reflejándose en aquello de que dispone, trátese de un artilugio o de una imagen onírica" (Fericgla, 1998: 120-121).

En síntesis podemos decir que los objetos al ser donados crean un campo de relaciones que suplantan a las personas. En otras palabras, los objetos serían la proyección o los dobles fantasmales de las relaciones que tienden los agentes culturales -en y por el don-. De forma que los objetos en definitiva son poseídos pero no alienables en cuanto a la relación establecida en el traspaso, como lo afirma Godelier (1998), y así, son objetossujetos de ser dados y devueltos asegurando que se mantenga el don ad infinitum. 
Siguiendo con lo anterior, nos referimos específicamente que en los rituales de ayahuasca se pone en práctica la función dialógica de la mente que establece conexión profunda con los dobles de los objetos; el trance chamánico de la conciencia establece esta conexión sagrado-mágico-religiosa, y con ello el Yachac reformula la significación de símbolos profundos en consonancia con los objetos -sagrados como preciosos- y su influencia en el ámbito de las relaciones sociales. Es decir, interfiere originando modificaciones presentes en el fondo que son las ondas pulsiones del imaginario, pero materializadas en la forma como puede ser la adopción de otros objetos "sagrados” de uso como imágenes, figurinas, palabras, cristianas o chamánicas de otras latitudes, etc., a manera de transculturación.

Es decir que los espacios rituales de ayahuasca son vitales, ahí se recrea el tiempo sagrado fundamental para la poiesis cultural, en el que se plasma el "hecho social total", con un sentido un tanto distinto al que observaba Marcel Mauss.

"En efecto, podemos considerar que los fenómenos sociales son "totales" no porque combinen en su interior múltiples aspectos de la sociedad, sino porque en cierto modo permiten que la sociedad se represente y reproduzca como un todo" (Godelier, 1998: 64).

Con todo esto no decimos que los chamanes sean conscientes de su estructuración cultural, porque ese no sería un aspecto importante y necesario de ser comprendido en su cultura; decimos que por el trance chamánico y la subyacencia del don se reformula el imaginario que permite la circulación de objetos y por ende el reestablecimiento de las relaciones de intercambio, lo cual mantiene el sistema cultural en balance asegurando al fin la reproducción de la cultura como tal.

\section{"Comprar lo que no se puede vender": la relación con el etnoturismo}

En nuestro tiempo el hacer turismo se lo percibe como una actividad muy común, hoy por hoy es una importante fuente de ingreso económico alrededor del mundo que se constituye en el sustento económico de algunos países y, en este caso, de las comunidades ofertantes.

El turismo en la región del Napo prácticamente empieza tras la apertura de carreteras, las que fueron propiciadas a partir de los años 70 por la presencia de la novísima industria petrolera. En sus inicios, el turismo se lo realizaba de manera muy informal o con agencias especializadas, puesto que las carreteras aún no estaban bien reafirmadas.

A partir de los años 80 el turismo empieza a cobrar fuerza, y con él, la actividad comercial se incrementa en las áreas del Tena, además de Puerto Misahuallí y Archidona.

Cabe esclarecer que la actividad del turismo como tal es una práctica muy nueva en el mundo, se puede decir que es una práctica contemporánea que responde a un nuevo tipo de necesidad. Más en términos reales, tan sólo el 5 o 10\% de la población mundial tiene la capacidad de viajar al menos una vez por turismo. Es de notar que la necesidad real se manifiesta por el imaginario e ideología que plantea esta fase civilizatoria del capitalismo, categorizada como un "sistema-mundo" (Wallerstein, 1997: 53), y como tal tiene toda una visión valorativa acerca de la civilización, del progreso, de lo salvaje o exótico del chamanismo, etc., es decir la preponderancia de un único sistema histórico. 
"En pocas palabras, el concepto "civilización" reflejaba el triunfo intelectual de la "ciencia racional y experimental" expresado por pensadores de la Ilustración para todos los que, como dice Febvre (1962) "la civilización es antes que nada, un ideal y, en gran medida, un ideal moral" (Wallerstein, 1997: 21).

De manera que el turismo se encuentra dentro del sistema de economía de mercado, y como tal se ha popularizado como una actividad en la que se viaja a un lugar distante, en lo posible diferente, dentro de un tiempo que paradójicamente se puede llamar "libre" de trabajo o mejor dicho en un tiempo de ocio.

La característica de fondo es que en este tiempo de turismo no se escapa a la lógica económica contemporánea, puesto que es un tiempo en el que no se trabaja pero que se sigue consumiendo, es un sistema regulatorio que dinamiza el ocio en función del capital, será entonces una forma sofisticada de consumo. En este tiempo de ocio y espacio de turismo se han de consumir las imágenes que se las han interpuesto con anterioridad, en otras palabras las imágenes prefiguradas que venden las agencias de turismo, el internet, la televisión, etc. Aspecto que Guy Debord (2003) llama como "sociedad del espectáculo".

De forma que, en el sistema mundo capitalista no sólo se controlará la producción en el tiempo de trabajo, sino que también se lo hace en el tiempo de ocio, con lo que se deriva que existe todo un código sígnico en su lógica civilizatoria.

"El espectáculo, entendido en su totalidad, es al mismo tiempo el resultado y el proyecto del modo de producción existente (...) El espectáculo no es un conjunto de imágenes sino una relación social entre las personas mediatizadas por las imágenes (...) Allí donde el mundo real se transforma en meras imágenes, las meras imágenes se transforman en reales, y en eficaces motivaciones de un comportamiento hipnótico (...) Es la omnipresente afirmación de una opción ya efectuada en la producción, y su consiguiente consumo" (Debord, 2003: 38,43).

Las relaciones interpersonales estarán en gran medida signadas por el uso del dinero a manera de un código cultural, en la que la relación con los objetos marca el tipo de relaciones sociales o a la inversa. Así, se puede ver que, mientras las sociedad Napo Runa se mueve dentro de un campo en el que los objetos-símbolos tienen relación con su significado profundo (reciprocidad), dentro de la sociedad occidental tal relación está escindida, de tal forma que es un código sígnico, en la que Baudrillard (1976) mira una lógica diferencial permanente, apoyado por una dinámica de consumo.

El consumo será pues el dinamizador social civilizatorio del cual se valen en mayor o menor medida los turistas. En otras palabras, la diferencia de lógicas culturales respecto a los Napo Runas se debe a que en el valor "símbolo", referido para la relación del don, el objeto desaparece como tal apareciendo su doble que serán las relaciones de las personas; en cambio en occidente el "signo" hace que el objeto se deifique adquiriendo independencia de relación: "el objeto-signo sólo remite a la ausencia de la relación” (Baudrillard, 1976: 37). "El dinero es el signo único de un logos demiúrgico que actúa permanentemente de ruptura de contacto entre sus significantes y sus significados; discurso del Capital que se nutre del desequilibrio de su referencial" (Girardin, en Baudrillard, 1976: 11).

Entonces el dinero será el objeto "precioso" necesario que configura en occidente la realidad económica y la social. Éste cobra representación social al ser un objeto altamente simbolizado que sirve como referente de valor de las mercancías. Es decir que se privilegia el valor de cambio sobre el valor de uso. 
Aquí es donde se problematiza el consumo de rituales de ayahuasca, ya que ésta es una experiencia que debe ser comprada para ser vivida, en el que el valor para asistir a una ceremonia no tiene parangón con alguna otra cosa de las sociedades modernas, en otras palabras no tienen mercancías equivalentes que les indiquen un valor de referencia, lo cual a su vez tergiversa el sentido cultural Napo Runa, desdibujándolo.

Como vemos, se van aclarando las diferencias estructurales entre la celebración tradicional de un ritual Napo Runa y por otro lado, el consumo de él por parte de los etnoturistas. Podemos continuar estableciendo diferencias comparativas si nos enfocamos en los "fines - empleos" y asimismo las "funciones" de uso. Son instancias que difieren según el contexto cultural como sigue: a) en el uso ancestral de los Napo Runa dentro de un escenario ritual con afán colectivo y b) en el ámbito de los etnoturistas su uso se circunscribe a la acción de consumo del ritual con afán individual (aunque con diversas motivaciones personales para la ingestión de la pócima de ayahuasca).

De manera que, para el caso de los etnoturistas las cualidades serán muy distintas a las ya vistas de los Napo Runas. La pócima de ayahuasca dentro de su contexto cultural puede ser catalogada con el genérico de "droga"; no obstante, este apelativo es muy impreciso si consideramos que varios tipos de "drogas" tienen matices diversos en concordancia con sus "fines" y "funciones" como: sedación, euforia, conformidad, aquietamiento, aturdimiento o embrutecimiento.

Para el caso de la ayahuasca sus características son las de ser una "droga" o mejor dicho un fármaco que aumenta la oxigenación cerebral para dar campo a la vivencia del éxtasis, lo que a decir de Escohotado sería una etapa en la que se moriría en vida, y para ello hay que pasar de lo beatífico a lo pavoroso, en la que se viaja a regiones inexploradas en las que hay miedo de volverse loco o estallar de significado: “...la reconciliación de lo finito con lo infinito, donde el instante y la eternidad se funden, emancipados de deudas para con el ayer y el mañana"(Escohotado, 2002:160).

En estos estados sobrevienen imágenes y criaturas de cualquier índole, para lo que el sujeto que las presencia se sabe inmerso, mas no se cree envuelto en ella como única realidad, a pesar de la angustia o del asombro que le pueda generar. Esta contemplación de estas otras realidades se lo puede llamar como una "visión", que no es sino la experiencia y admisión de lo inaudito, lo que a la postre genera expansión de la conciencia por la retención que se fijará en la memoria, muy al contrario de lo que ocurre con la alucinación con la que no se tiene noción de irrealidad y se actuará acorde y muchas veces sin memoria de lo sucedido.

La ayahuasca, bajo este enfoque estará considerada como un elemento que lleva a estimular a que la parte psíquica del conciente y del inconsciente se conecten, mejor dicho que el conciente y autoconsciente se comuniquen, pudiendo derivar en una experiencia conciliadora o bien en una experiencia terriblemente angustiosa.

Esto nos lleva a definirla como una "droga visionaria", con la que se busca conocimiento de las realidades más íntimas, o bien una excursión psíquica. De tal forma, que lo propio sería denominarlos como un "turismo psiquedélico", pero como la acción de ingestión de

7 Vivanco se refiere al "turismo psiquedélico" como un turismo que compra y mercantiliza el cactus de San Pedro en las inmediaciones del pueblo de Vilcabamba en su libro: "Vilcabamba: conflictos culturales, prácticas y discursos en torno al uso del San Pedro, 2000 . 
la pócima también incluye la observación del ritual y la mediación del Yachac (chamán), lo propio sería llamarle "turismo etnoespiritual" como se refiere Rogers (1997) en su estudio en los Andes.

Dejamos entrever que al llamarlo "turismo etnoespiritual" existe un tipo de motivación distinta que escapa al constreñimiento del modelo civilizatorio occidental. Es decir, que a más del viaje de turismo la búsqueda del etnoturista estará por fuera de las instituciones clásicas tradicionales, con ello se aprecia que han perdido legitimidad o representatividad y por lo tanto el sentido.

A esta nueva corriente se la ha denominado como "New Age" 8 , y es novedosa puesto que no constituye una religión en sí, sino una tendencia que nació como un intento de resurgir la espiritualidad perdida en occidente. Trata de suplantar los puestos dejados por las grandes instituciones occidentales religiosas: de enseñanza, espirituales, gubernamentales, etc., todas éstas erosionadas de sentido y de representatividad.

Si bien los etnoturistas no confieren para nada dentro de esta nueva corriente, vemos que muchas de las cualidades encontradas encajan con el fenómeno. Nos referimos, a que para el caso específico de hacer turismo etnoespiritual existirá un motor ideológico que estará por detrás sin ser plenamente asumido por ellos.

Como primer punto hay que plantearse que el "New Age", es un fenómeno que integra saberes ancestrales de todo el mundo a manera de collage; no obstante, cabe partir de que el fenómeno se mueve dentro del carácter irracionalista, ocurre una especie de subversión del carácter logiscista y racional de la sociedad occidental. Por ello se puede notar que los etnoturistas, por el hecho mismo de poder hacer turismo, no serán un estrato general de su sociedad occidental, sino que tienen la posibilidad de viajar y con él de buscar más allá de su propia configuración civilizatoria. Esto nos dice a claras que el matiz general que se incrementa en nuestra sociedad es la "falta de sentido". Siguiendo a Bosca, esto se lo puede notar por la declinación general de las ideologías y la crisis de la idea de progreso. Luego, los etnoturistas serán agentes de su sociedad pero insatisfechos de la misma, por eso buscan por fuera de ella lo que su propio medio cultural no puede ofrecerles (Bosca, 1994: 17).

La insatisfacción cultural occidental puede acercarlos a ver a la ayahuasca ya no como una droga, sino como una medicina espiritual que les justifica la vivencia. La motivación para vivir los efectos de la ayahuasca ronda especialmente el ámbito de la subjetividad, bajo ésta se pueden encontrar las siguientes características: la comunión directa con la realidad última sin mediaciones institucionales; la experiencia sobre el dogma; una subjetividad autosuficiente; descubrimiento del yo o de la identidad; conexión personal con "lo puro original" y con "la naturaleza".

Lo que se ve es que los etnoturistas no pueden escapar a los códigos de su racionalidad económica, pero pueden experimentar vivencias al margen de lo común y lo aceptable. En todos los casos observados no contaban con un contrato con alguna empresa turística que organice y controle su estadía y actividades, de manera que no tuvieron la re-presentación del ritual por parte de las compañías de turismo, además de que estas experiencias son tan profundas que no pueden ser emuladas para ser promocionadas libremente, pese a que la ayahuasca no está penada por ley. 
Por otro lado, la compra del ritual de ayahuasca significa hacerla mercancía, pero que no podrá estar expuesta de manera clara a los valores del mercado porque se trata de una sustancia que altera la conciencia y que no puede entrar en los códigos occidentales de racionalidad y peor tener una funcionalidad dentro su sistema cultural, por eso es que generalmente la llaman genéricamente "droga”, una denominación con vacío de significado a ser re-llenado como la antítesis del ser social.

Por todos estos matices señalados, tenemos que el etnoturismo, bajo el influjo globalizado del "New Age", busca que la "otredad" (Napo Runa) se haga visible, es más su contacto se hace deseable y necesario, por lo visto, tendrá muchos imaginarios que cruzan de por medio sus intereses. Este acercamiento es un tanto paradójico, Trujillo (2001) indica que antes se los quería ver "civilizados", en cambio hoy en día se los quiere ver "salvajes", "puros", "mágicos", "poderosos", etc.

El turismo a diferencia de otros procesos vividos en la misma región, como el del caucho, misiones religiosas, petróleo, ya no tiene un acercamiento en la negación propiamente del "otro", sino que más bien promueve en apariencia su existencia como razón de ser del etnoturismo; sin embargo, puede verse que la misma interrelación no garantiza un acercamiento intercultural, esto se puede evidenciar claramente por los códigos culturales distintos y el idioma que marca una distancia comunicativa insalvable dentro de los rituales. Además, si consideramos la corta estancia de los etnoturistas y las preconcepciones con las que están cargados, no se podrá dar un espacio de reconocimiento.

Para terminar vale remitirse a que pese a las buenas intenciones que pudieran tener los etnoturistas, en sus códigos se encuentra un "sistema-mundo" que está inmerso en el capitalismo mejor llamado como "imperio-mundo" (Wallerstein, 1997), y como tal es muy distinto al de la sociedad Napo Runa, comprendida como un "micro-sistema" que coexiste con el otro. No obstante, la presión que ejerce el "imperio-mundo" sobre este último es muy fuerte, obligándolo a adoptar cambios culturales.

Para ilustrar lo anterior podemos mencionar que el etnoturismo, al no estar dentro de un sistema cultural chamánico, no tendrá referentes de lo sagrado, por ende, carece de relaciones dentro de la lógica económica del don, y con ello vemos que los objetos sagrados que se guardan y que están en contacto con el mundo de lo divino no son comprendidos por los etnoturistas en el "afuera inmaterial" que crea jerarquía y deuda, sino en el "sí mismo" experimentable. Aquí Bosca (1994), se refiere a que los etnoturistas buscan una experiencia espiritual no en lo exterior o en la trascendencia sino en la inmanencia o en la experiencia palpable interior que brinda la ayahuasca (en este caso), es el Dios que puede experimentarse en el "sí mismo". Es decir, que su sistema cultural basado en el capital puede mercantilizar el ritual, y a la experiencia ponerla al nivel y servicio de la individualidad sin perder muchas veces el horizonte de la vivencia cognitiva profunda. El mismo autor lo llama como un "materialismo espiritualizado", o la síntesis entre un puro espiritualismo negador de lo material y un craso materialismo sin espíritu.

\section{Conclusiones}

Como vemos, la interrelación entre las lógicas sociales/económicas del etnoturista y el Yachac es altamente compleja. Los breves encuentros que suponen los rituales son 
propiciados por el fin subjetivo y personalista de los etnoturistas. La compra de rituales se demandarán en la medida de la experimentación subjetiva vivida por el etnoturista y en la medida del aspecto performático presentado por el chamán, mas no interesarán las resonancias que los símbolos pudieran contener.

Por este motivo es que el etnoturista se relaciona con el Yachac en un mismo espacio pero no comparten un mismo tiempo, puesto que el tiempo de lo sagrado sólo será asequible para el contacto con las divinidades y el intercambio con estos seres. Este contacto lo podríamos denominar como un "autismo cultural", ya que del lado de los etnoturistas existe esta aceptación del "otro" pero en su re-presentación, lograda por la "sociedad del espectáculo", así, la representación del Yachac no se da enteramente por el contacto sino por su prefiguración antes de ello.

En cambio, por parte del Yachac y los Napo Runa, los etnoturistas son incluidos y se integran en su dinámica social pero a la vez no constituyen parte de su conformación cultural. Entonces cabe preguntarse, ¿de qué manera se produce esta integración sin su plena incorporación?

Los rituales que el Yachac vende a los etnoturistas en principio carecerán de los referentes simbólicos que son normalmente expuestos a la gente de su cultura, puesto que su uso resultaría fútil al no estar familiarizados. Por otra parte, la mayoría de rituales comprados no se deben a enfermedades graves sino a "limpias del espíritu". El Yachac, a causa del lenguaje y del contexto cultural, no podrá aconsejar modos de vida, ni interpretar sus sueños y peor aún contar un mito o cuento que tenga resonancias emocionales más allá del sesgo intelectivo. Así, su acción es muy reducida al no poder integrar sus funciones política, religiosa y curativa. A lo sumo, tan sólo podrá aplicar su función curativa, muy distinta a la capacidad de sanar en todo su sentido cultural; sólo podrá "curar" la enfermedad distintiva del etnoturista, que es caracterizada por el Yahac como enfermedad "mental", muy diferente a las enfermedades culturales conocidas, de tipo: "corporales", "semi-divinas" y "espirituales".

Vemos que el ritual y la terapia no cambian sustancialmente en cuanto a su forma, pero se simplifican por carecer del contexto cultural. Con esta relación la función del Yachac adopta un papel culturalmente distinto; el "autismo cultural" hace que éste se convierta en actor de su propio ejercicio, puesto que la interrelación con los etnoturistas estará de plano escindida. En apariencia, el rol del Yachac cambia radicalmente, su acción podría parecer como una teatralización vacía de sentido y la venta de ayahuasca podría aparecer como parte de una acelerada aculturación. Pero este cambio es estratégico y emerge como necesario dentro del contexto de la modernidad, asegurando la configuración de su sistémica cultural chamánico, como lo veremos a continuación.

El ejemplo que mejor ilustra lo anterior se lo pudo apreciar en una ocasión cuando el Yachac retornó de una "gira" internacional por los Estados Unidos. En total estuvo seis meses junto a su esposa e hijo mayor realizando gran cantidad de rituales de ayahuasca y ganando mucho dinero por ello. A su regreso terminó de construir una casa dentro de los predios de la comunidad, ahí depositó los electrodomésticos recién comprados como: lavadora de ropa, equipo de sonido, refrigeradora y motor generador de energía. En 
honor a su llegada y la de sus acompañantes se realizó una gran celebración en la casa y llenaron de comida a la refrigeradora, abastecieron de combustible al motor y probaron el lavarropa. Aquí asistieron sus parientes cercanos y lejanos y gente de la comunidad en general. Cuentan que en el ambiente de celebración el Yachac empezó a repartir dinero suelto a sus pequeños sobrinos/as. El festejo se prolongó por algunos días en la nueva casa de vivienda. Sin embargo, con el pasar del tiempo y su estadía en la casa, los recursos se fueron agotando, lo que significa que el combustible del motor se acabó y con él, se cortó el flujo eléctrico, por ello, los alimentos dentro de la refrigeradora perecieron y la lavadora y el equipo de sonido quedaron inutilizables. Por esta razón decidieron dejar la casa y sus enseres para regresar a su morada original, un poco más distante de la comunidad pero más próxima a las chacras y a los animales.

¿Qué nos dice este caso? Si estimamos lo que representa llevar electrodomésticos a una comunidad donde no llega la luz eléctrica, sin duda despertará nuestro desconcierto absoluto, talvez al punto de parecer el ejemplo más plausible de irracionalidad hilarante. Pero lo que refleja este ejemplo es el funcionamiento de su sistema cultural. Primeramente nos debemos enfocar en los préstamos que el Yachac realiza a sus parientes cercanos, ahí ya se pudo vislumbrar la generación intencionada de deuda y, por lo tanto, el reestablecimiento de la distancia asimétrica de la obligatoriedad de devolver, lo que se traduce en el afincamiento de su estatus y jerarquía. De igual forma, el poseer equipos eléctricos en una comunidad que no los tiene es la muestra de la supremacía de tener nuevos objetos "preciosos" provenientes de la cultura occidental. Así, vemos que la valoración en los objetos es traducida de una cultura a la otra pero con un trasfondo distinto.

Esta puesta en escena del Yachac es una forma de ganarse un estatus más alto en la comunidad y de recobrar un reconocimiento que gradualmente se está diluyendo, lo que en definitiva asegura por un tiempo la permanencia de sus funciones. Es decir, que los mismos valores foráneos que minan sus sentidos culturales son igualmente reformulados y usados para la pervivencia de su sistema cultural chamánico, esto puede ser visto como un "camuflaje" que permitirá el intercambio de cosas (mediante el don) en pro de asegurar la reproducción cultural. En otras palabras, se valen de un valor cultural ajeno y lo integran para reforzar y proteger su propio sistema cultural frente a la lógica civilizatoria que los presiona. En este escenario, el espacio de los rituales de ayahuasca será una fuente de subsistencia y a la vez el nódulo bajo el cual se incorpora y amortigua el cambio cultural; su dinamismo se extiende hasta el punto de compatibilizar su sistema cultural con los valores del contexto circundante, ya que los extremos, tanto de un exceso en la incorporación del cambio como en la extrema inmovilidad, desmoronarían todo su sistema de creencias.

Hay que considerar que los Napo Runa históricamente se han nutrido de las injerencias foráneas para constituirse como etnia, y el chamanismo ha sido el eje gravitante por el que, a pesar de los cambios, ha mantenido su configuración cultural en resistencia a la aculturación.

Por lo tanto, debe decirse que su cualidad es la de ser un sistema abierto, un sistema complejo que se nutre del movimiento para mantenerse en balance, incorporando constantemente aspectos culturales externos, tal es el caso de su reconocido sistema 
etnomédico desarrollado con las influencias venidas de todo lado (Morin, 1997: 44). Ésta ha sido su cualidad y no es de sorprenderse que siga siéndolo.

Pero la importancia que reviste este caso en particular, a diferencia de procesos de explotación anteriores como: el caucho, misiones religiosas, petróleo, etc., es la adaptación cultural a un proceso no directamente violento que se está gestando dentro del campo de lo sagrado. Ésta será la gran diferencia.

El uso ritual ancestral de la planta de ayahuasca es de fundamental importancia para mantener estable el campo de lo sagrado, ya que los vincula al mundo "inmaterial" del cual se sostiene su cultura. No obstante, el modificar su uso con la venta de rituales es otra manera nueva de estabilizarlo, por el momento funciona como argamasa para ubicar dentro de un nuevo contexto a sus agentes culturales. De igual manera, se podría afirmar que se trata de una estrategia culturalmente arriesgada, ya que operar en el campo de lo sagrado, expone el nódulo o la fractura por donde se podría colar toda una lógica estructural ajena de relaciones sociales y económicas.

No se puede desconocer que estas dos lógicas se encuentran enfrentadas en tanto sistemas distintos: un "mini-sistema" Napo Runa que se relaciona al de "economíamundo" o mejor dicho al "imperio-mundo". El primero incorpora elementos del otro sistema imperante, pero es una acción que tiene por desventaja la posible distorsión del sistema y la consecuente pérdida de sentido.

Hay que tener presente que el proyecto universalista de este último sistema regula y des-encanta los objetos y relaciones de lo sagrado; su misión "civilizatoria" conspira subrepticiamente contra los modos de vida subalternos, en este caso contra la salud cultural de los Napo Runa.

Por lo tanto, la disposición de venta de rituales es una apuesta que el Yachac realiza, no se sabe si esta estrategia traerá resultados óptimos o por el contrario nefastos. La presión del medio los ha obligado a tomar medidas que aseguran su reproducción cultural; en todo caso es una estrategia en la que se acepta la injerencia cultural al tiempo que se la rechaza, es decir una contradicción o un camino de aparente irracionalidad mediante la que se ha escudado su resistencia.

Por el momento el sistema se conserva en su parte medular, lo que no se sabe es hasta cuándo podrá hacerlo ya que la presión se ejerce por varios frentes. El medio ambiente circundante está siendo deforestado y con él los lugares sagrados y consiguientemente la visión animista y de complementariedad que conforman el modo de intercambios sociales.

El panorama futuro de los Napo Runa, dependerá del tipo de contacto o diálogo intercultural que se plantee, puesto que la globalización podría ser una oportunidad para el autoreconocimiento de su identidad, y por el contrario también podría resultar el espejo que revista su imagen y por el que se despoje a su ser cultural, volviendo a la cultura Napo Runa folklórica, vacía y funcionalmente indiferenciada. 


\section{Bibliografía}

Augé, Marc, 2004, Los no lugares: Espacios del anonimato/ Una antropología de la sobremodernidad, Gedisa, Barcelona.

Baudrillard, Jean, 1976, Signos para una Política: Lectura de Baudrillard, Barcelona, Editorial Anagrama, Preludio de Jean-Claude Girardin.

Bosca, Roberto, 1994, El New Age, Atlántida, Buenos Aires - Argentina.

Debord, Guy, 2003, La sociedad del espectáculo, Pre-textos, España.

Escohotado, Antonio, 2002, Aprendiendo de las drogas: usos y abusos, prejuicios y desafios, Barcelona, Editorial Anagrama.

Fericgla, Josep, 1999, "El peso central de los enteógenos en la dinámica cultural”, en: Revista Maguaré.

No. 14, Departamento de Antropología, Universidad Nacional de Colombia. No. 14, Bogotá, Colombia.

1998, El chamanismo a revisión: de las vías extáticas de curación al Internet, Abya -Yala. Serie Plurimenor, Quito.

Geertz, Clifford, 1997, La interpretación de las culturas, Gedisa, Barcelona.

1996, Los usos de la diversidad, Paidós, Barcelona.

1973, Ethos, Visión del Mundo y Análisis de símbolos sagrados. Lima, Pontificia Universidad Católica del Perú, Área de Antropología, Dpto. Ciencias Sociales.

Godelier, Maurice, 1998, El enigma del Don, Paidós, Barcelona.

Goldáraz, José Miguel, 2004, Mushuk Pacha/ Hacia la tierra sin mal, Cicame, Quito.

Hampejs, Heinz Valentin, 1995, El éxtasis Shamánico de la Conciencia: principio medular de la medicina shamánica, Abya -Yala, Quito.

Iglesias, Jenny, s/f., Sacha Jambi: el uso de las plantas en la medicina tradicional, Abya-Yala, Quito.

Jodorowsky, Alejandro, 2006, Psicomagia, Grijalbo, Chile.

Khon, Eduardo, 1992, La cultura médica de los Runas: de la región Amazónica Ecuatoriana, Abya -Yala, Quito.

Morin, Edgar, 1997, Introducción al pensamiento complejo, Gedisa, Barcelona.

Muratorio, Blanca, 1987, Rucuyaya Alonso y la vida social, económica del Alto Napo 1850 -1950, Abya -Yala, Quito.

Naranjo, Plutarco, 2007, "Las plantas sagradas en la arqueología y antropología en Ecuador, en Sotomayor", en: Hugo A. y Zoilo, Cuellar, Aproximaciones a la Paleopatología en América Latina, Convenio Andrés Bello/ ALANAM, Bogotá.

1983, Ayahuasca: Etnomedicina y Mitología, Libri Mundi, Quito.

1978, “Medicina Indígena y popular de América Latina”, en: Revista Ecuatoriana de Medicina, Vol. XIV. No 4, Casa de la Cultura Ecuatoriana, Quito.

Perrin, Michel, 2002, El Chamanismo, Acento Editorial, Madrid.

Rogers, Mark, 1997, "El turismo etnoespiritual y el cambio religioso: influencias recíprocas entre el chamanismo andino y la terapia "New Age", en: Libro de Resúmenes, $49^{\circ}$ Congreso internacional de Americanistas, Tomo I, PUCE, Julio 1997, Quito. 
Rueda, Vinicio, 1993, Mitología, Universidad Católica del Ecuador.

Sanhueza, Ricardo, 1986, Etnomedicina en la provincia de Manabi, Tesis de disertación previa a la obtención de Licenciatura en Antropología, Pontificia Universidad Católica, Quito.

Sharon, Douglas, 1998, El Chamán de los cuatro Vientos, Siglo XXI, México.

Trujillo Montalvo, Patricio, 2001, Salvajes, civilizados, civilizadores/La Amazonía Ecuatoriana: espacio de las ilusiones, Abya -Yala, Quito.

Vivanco, Eliana, 2000, Vilcabamba: conflictos culturales, prácticas y discursos en torno al uso del San Pedro, Tesis de Licenciatura en Antropología, Pontificia Universidad Católica, Quito.

Wallerstein, Inmanuel, 1997, El Futuro de la civilización capitalista, Icaria, Barcelona.

Wasson, R. Gordon, 1983, El Hongo Maravilloso Teocana'catl: Micolatría en Mesoamérica, Fondo de Cultura Económica de México, México.

Wray, Natalia, 1996, “Amazonía: Economía indígena y Mercado/ Los desafíos del desarrollo autónomo”, en: Wray, Natalia et. al., Hacia el desarrollo autónomo: los indígenas amazónicos en el camino hacia el desarrollo autónomo, COICA-OXFAM América, Quito. 


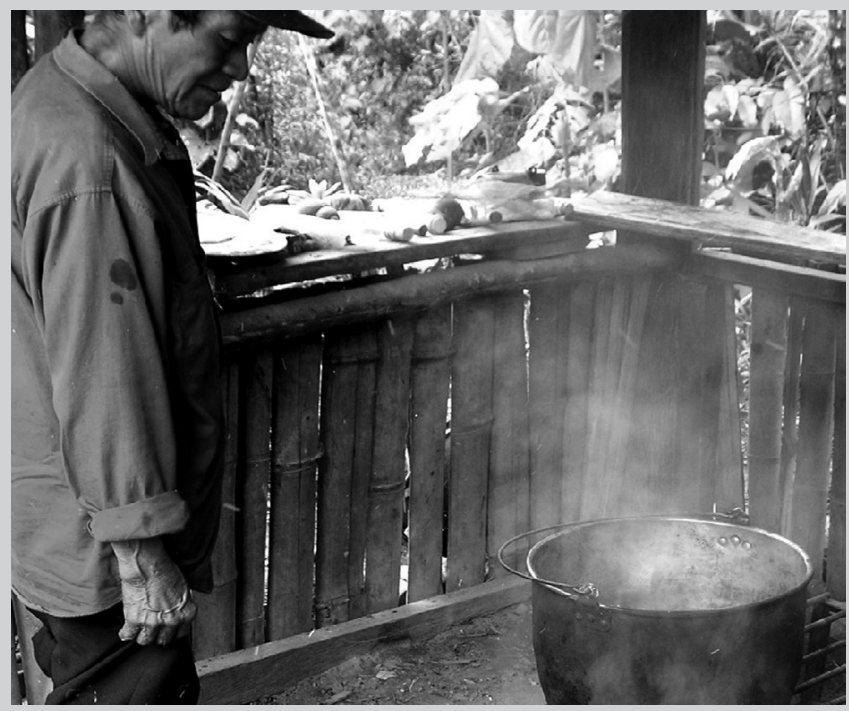

COCINA DE AYAHUASCA:

La planta medicinal de Ayahuasca es cocinada a diferentes horas del día y en diferentes lugares, según la ubicación temporal de la cocina. La cocción de este bejuco toma alrededor de 6 horas y requiere cuidados para saber el punto de estado adecuado. No existen tabúes en cuanto a la permisión de observar la pócima por parte de mujeres o extraños. Cuenta el yachac que su abuelo la cocinaba en olla de barro y no permitía que entren y vean las jovencitas, pues se creía que levantaban polvo y eso hacía vomitar en los rituales y no tener la "visión".

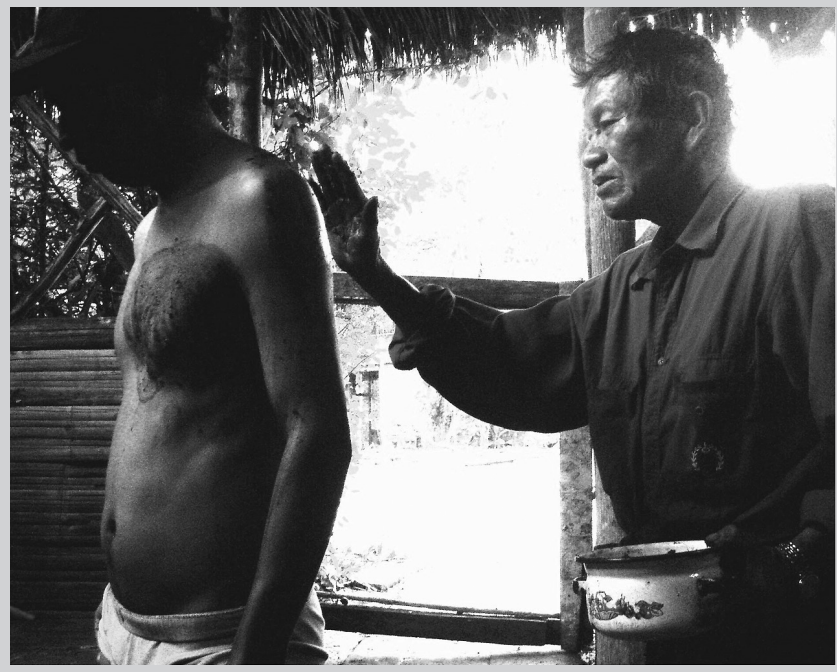

\section{CURACIÓN PACIENTE:}

Para curaciones en afeccione cutáneas severas el yachac aplica directamente un ungüento preparado con plantas medicinales. En la aplicación bordea las zonas periféricas afectadas para luego cubrir en su totalidad. En otras zonas aparentemente sanas traza cruces cristianas y realiza imposición de manos. Durante el tratamiento el yachac sopla la afección, lo cual dentro de su cosmovisón puede interpretarse como una insuflación o el envío del "samay" para la restauración del paciente. 


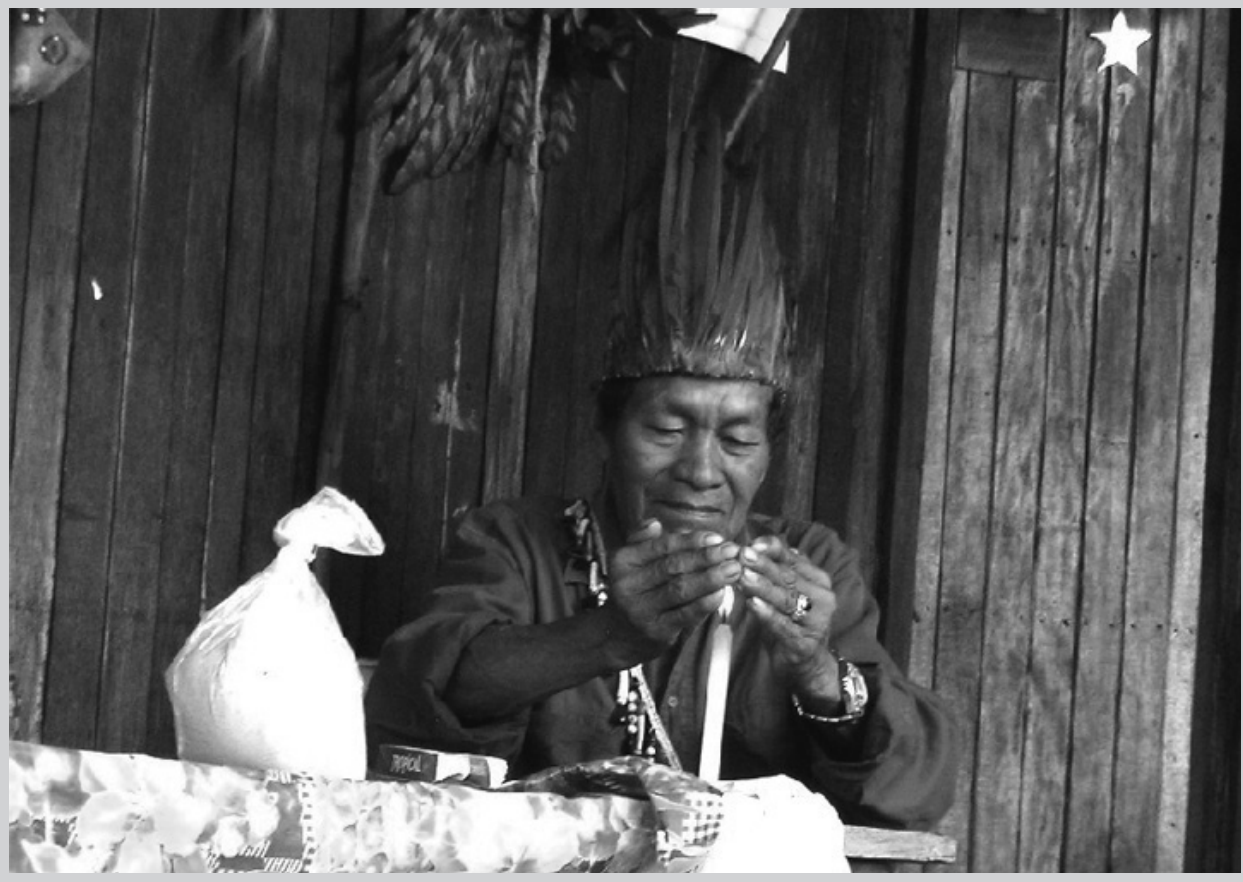

\section{LECTURA DE VELA:}

Para la "lectura de vela", el yachac realiza gran cantidad de gesticulaciones con las manos, que son como una herramienta que le conducen a la revelación, sin antes demandar notable dosis de concentración.

Es necesaria una vela por cada caso, los intereses son variados y van desde la buena suerte; para el cuidado de bienes materiales como un carro o una moto; para saber la forma de ser de la persona y los males que le atañen; y para ver el presente y futuro de la salud del individuo, sea que esté ahí presente o no lo esté.

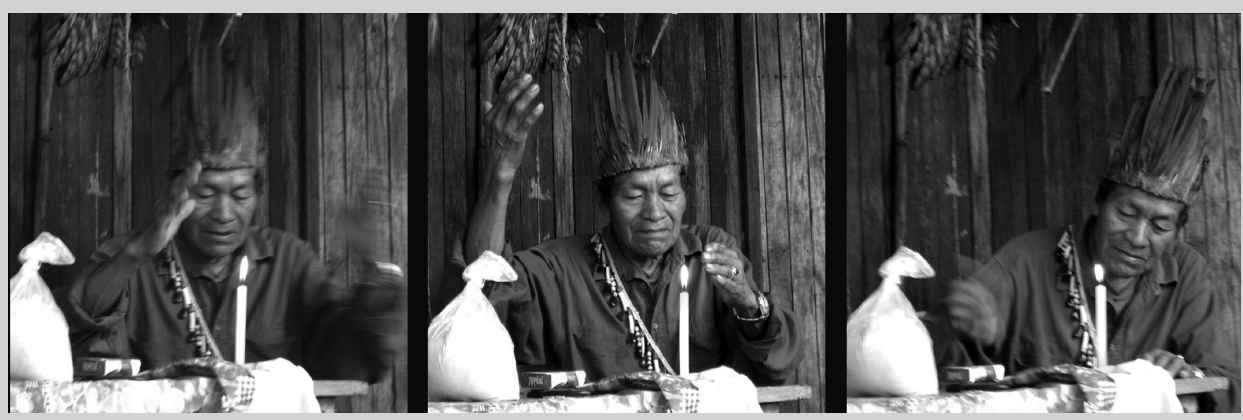

